\section{AIDS ... again} Knowledge that something is dangerous is not neces-
sarily a sufficient inducement to change behaviour.

WHERE the older generation of gay men changed their sexual behaviour in the face of HIV, the younger generation is experiencing an increased incidence of infection among homosexuals. Recent data compiled by epidemiologists at the University of California at San Francisco (UCSF) indicate that one in three men who are homosexual or bisexual will be HIV-positive by the time they are 30 years old.

Simply put, these data say that the deadly AIDS message, which penetrated the lives of older men who have witnessed the deaths of dozens of their friends, has not been passed on to teenagers and young adults. But the virus is being passed on with negligent abandon among young men who knowingly chose to practise unsafe sex. According to reports of work by Dennis H. Osmond of UCSF and colleagues, even though these young people (many of whom have been to AIDS counselling sessions) know they are at risk, knowledge alone does not change their behaviour.

These troublesome data merely confirm the weak -tonon-existent link between what one might call 'book-learning' or knowledge from lectures and behaviour. Recent studies of homosexual and heterosexual couples in Europe, in which one partner was known by the other to be HIVpositive, showed that 52 per cent had unprotected sex nonetheless (see Nature 370, 400; 1994).

What is it that makes people take such serious risks? Is it youth - simple as that? Or are there other factors particular to the issue of safe or unsafe sex and AIDS? The answers to date amount to little more than pop-psychology, which is not enough.

\section{Clinton's indecision}

\section{US president Bill Clinton's "policy" on the Cuban refugee crisis speaks volumes about his presidency.}

As the world watches in horror, thousands of Cubans, fleeing their homeland in search of a better life, are crowding into rafts and putting out to sea in search of America. But America, under policy set forth by US president Bill Clinton, is turning them away. The president's reasoning, which is a bit difficult for a sensible person to follow, is that he will not allow Fidel Castro to dictate US immigration policy.

The city of Miami, Florida, is already a haven overflowing with Cuban refugees who have transformed the cultural identity of the place. And some of the very people who were allowed to immigrate in years past are now taking a "not-inmy-backyard' stance with regard to their former fellows. 'There is not enough room for more of us', some are saying in effect, giving the president ammunition for his no-admissions policy.

As a half-way measure, Mr Clinton has adopted one of the least humane and least effective policies he could have. He has stationed US ships in the ocean midway between Cuba and Florida, with instructions to intercept refugees and return them where? To Cuba. Not to their homeland, but to a US base at Guantanamo Bay where they are massed together in crowded tent cities.

So - what does this say about Mr Clinton? That he seems to lack the capacity to anticipate the future. As long as two years ago, scholars were predicting precisely the quagmire that the Clinton administration is now in. A year ago, the Central Intelligence Agency was issuing classified warnings to the White House. And officials at the State Department were also fully cognizant of a looming international relations disaster with Cuba. Nor has Mr Clinton shown himself particularly adept at dealing with the predictable now that it has occurred.

His ability to deal with the crisis in Haiti is equally dismal. There, too, expensive, disease-ridden tent cities erected by the US military sometimes make it difficult to tell the difference between the Caribbean and the sorrowful state of refugees in Africa.

Mr Clinton has taken a middle road to disaster by neither fully admitting nor definitively rejecting the refugees probably heading for US shores. It is a telling statement about his leadership in international affairs.

\section{Is health reform dead?}

Mr Clinton appears ready to compromise on health care reform despite previous denials.

THE comprehensive and deceptively costly program for health-care reform that US president Bill Clinton, Hillary Rodham Clinton, and consultant Ira Magaziner expected to sweep the public off their feet appears dead in the water, at least for this year. Neither Congress nor the US public has been able to fully grasp all of the ins and outs of the 1,342page plan that the Clinton team has been utterly unable to explain. That may be just as well because the dead plan was so full of intrusive provisions that no man, woman, child, or business in the country would have escaped the heavy hand of a well-meaning administration whose ideas for reform violate the Hippocratic oath to do no harm.

Individuals feared (rightly) that their choice of doctor would be limited. Small businesses said they cannot afford to pay workers' insurance premiums. Some politicians said the plan was too liberal; others said it was not inclusive enough. And no one could agree how to pay for it. In short, the Clinton plan (with its innumerable complexities) was an easy target, shot down often for the right reasons. It promised comprehensive benefits to everyone but, once its true dollar costs were revealed, looked too expensive even for a wealthy nation.

One irony of the latest news about health reform's demise is this: on the very day most observers declared that the Clintons' way would break the bank, surgeons in California performed open heart surgery on a young orangutan - a member of an endangered species. 